\title{
Historical Perspectives and the Emergence of the Sustainability Concept in Organizations
}

\author{
Hassan Mousa Haidar \\ Business Department, Jeddah International College, Jeddah, Saudi Arabia \\ Email: Hassan@jicollege.edu.sa
}

How to cite this paper: Haidar, H. M. (2021). Historical Perspectives and the Emergence of the Sustainability Concept in Organizations. Open Journal of Business and Management, 9, 2277-2298.

https://doi.org/10.4236/ojbm.2021.95123

Received: July 27, 2021

Accepted: September 10, 2021

Published: September 13, 2021

Copyright (c) 2021 by author(s) and Scientific Research Publishing Inc. This work is licensed under the Creative Commons Attribution International License (CC BY 4.0).

http://creativecommons.org/licenses/by/4.0/

\begin{abstract}
This paper commences by examining historical perspectives and the emergence of the concept in organizations. It is important to analyze the historical background of sustainability in order to document the theoretical approaches that have shaped it and continue to inform development in sustainability practices among organizations. Furthermore, the thin line between CS or sustainability and CSR has been noted, with the latter seemingly contributing a small part of the holistic concept of sustainable development. It also provides a theoretical construction and conceptualization of sustainability, as well as detailed perspectives on its importance and major drivers, both in the past and in the modern context. Finally, the paper documents the relevant models that explain the concept.
\end{abstract}

\section{Keywords}

Sustainability, Corporate Social Responsibility, Social Development, Ecological Environment, Stakeholder Engagement

\section{Introduction}

The historical origin of sustainability can be traced to environmental accounting, as premised on the ideals of corporate social responsibility (CSR) and corporate management practices, in tandem with the demands of external stakeholders on the environmental, economic, and social dynamics of businesses. According to Hyršlová, Becková, and Kubáňková (2015) and Haffar and Searcy (2017), sustainability represents a paradigm shift away from traditional accounting practices which concentrate mainly on the financial (economic) aspects of a business, and includes environmental accounting, which places greater emphasis on examining the economic aspects of a business's main environmentally related activities. Sustainability emerged in the 1960s and early 1970s when it was used in 
compiling stand-alone non-financial reports targeting external stakeholders or other parties (Kuhlman \& Farrington, 2010).

Notable social reporting on aspects of sustainability was conducted in France and the Netherlands, and later in countries such as Switzerland; Germany and Austria would follow suit by using stand-alone non-financial reports as the basis for environmental reporting by listed or public entities (Hyršlová et al., 2015; Salzmann, Ionescu-Somers, \& Steger, 2005). The idea of sustainability that would later be developed in 1975 was published as three-tier corporate social performance (CSP) model that focuses on social responsiveness, social responsibility, and social obligation (Munoz, Zhao, \& Yang, 2017; Sethi, 1975). According to the CSP model, organizations should undertake social responsibility by bringing organizational/corporate practice to a level deemed harmonious with prevailing expectations regarding returns, and with social value and social norms, by way of social responsiveness in anticipation of social problems and change when developing business policies (Sethi, 1975).

Later, in the 1980s, the negative screening movement would emerge, with investment funds across the US and Great Britain adopting an investment decision-making model that looked at an organization's ethical compliance and social performance standards in addition to the economic aspects of the business (Gray \& Kouhy 1993; Carroll, 1999). The movement was informed by the CSP model, and its proponents focused on enlightening investment firms about the need to consider environmental and social practices and the responsibility of organizations before making investment decisions. Most importantly, during 1980 s, the idea of sustainability was adopted by organizations in order to demonstrate their dedication to sustainable development and practices in response to the UN World Commission (UNWC) on Environment and Development; it also ushered in the UN Conference on Environment and Development in early 1990s (Gray \& Kouhy, 1993; Elkington, 1999).

Indeed, the first publication on sustainability occurred in 1989 when a number of listed firms decided to file environmental reports separately from their mainstream financial reports in order to document information on business sustainability or on social and environmental policies (Gray, 2010; Kolk, 2004; Kuhlman \& Farrington, 2010). Detailed scientific literature on sustainability appeared from the 1990s, with academics formulating abstract details of sustainability principles and application frameworks in the organizational context. For example, Gray \& Kouhy (1993) devised sustainability accounting premised on three methods: input-output analysis, sustainable costs, and natural capital accounting. As observed by Rappaport (1998) and Sveiby et al. (1990), at the dawn of the 1990s, analysis of the sustainability aspects of businesses was marked by the search for new, feasible indicators for ascertaining an organization's value based on non-financial and economic metrics. In 1997, a remarkable milestone for the sustainability aspects of an organization was realized following the establishment of two important governing bodies, the Global Reporting Initiative 
(GRI) and the Coalition for Environmentally Responsible Economies (CERES) (Dragomir, 2011; Montiel \& Delgado-Ceballos, 2014).

The GRI was introduced for the purpose of creating rules and regulations that govern reporting on the social, economic, and environmental conduct of organizations. In 1999, a more inclusive model was developed by expanding on Sethi's (1975) three-tier model to include a fourth element by focusing on: 1) ethical responsibility, 2) philanthropic or discretional responsibility, 3) economic responsibility or profitability, and 4) legal responsibility (Carroll, 1999; Munoz et al., 2017). At the same time, Elkington (1999) invented a sustainability approach that used triple bottom line (TBL) elements that focus on disclosing the social, economic, and environmental impacts of a company. Triple bottom line accounting elements formed the basis for the GRI guidelines, setting the trend for the increasing popularity of the sustainability concept using a globalized perspective on business practices. Indeed, the TBL approach became the basis for sustainability accounting, with the focus remaining on the disclosure of the financial, social, and environmental impacts of organizations (Carroll, 1999; Deegan, 2002; Gray, 2010). By the turn of the millennium, the majority of organizations emphasized the importance of the environmental and social aspects of their business activities, yielding to external pressure from stakeholders for the management of and reporting on social and environmental performance aspects and their impact on their immediate social context (Dragomir, 2011; Kuhlman \& Farrington, 2010; Kolk, 2004; Montiel \& Delgado-Ceballos, 2014).

As noted by Brown, De Jong, and Levy (2009), and Gray (2006), and Gray (2006), there has been growing awareness of social and environmental issues in business activities, thereby elevating the need for global regulation and the assurance of the reliability credibility of sustainability reporting by organizations. In recent years, the discourse has shifted towards voluntary or non-voluntary sustainability practices. Although, in some countries, sustainability practices are guided by mandatory regulations governing listed companies, the majority of jurisdictions are yet to develop a legal framework for guiding the sustainability activities of a business. Regardless of the shortcomings associated with insufficient legal frameworks, society has registered an ever-increasing awareness of sustainability. According to Kolk \& Van Tulder (2010), and Seuring and Muller (2008), society have has increasingly become aware of social and environmental issues, sustainable practices, scarcity of natural resources, and climate change.

Williams and Conley (2005) hold a similar view and observe that modern society has shown increasing awareness of social and environmental issues, as well as of the transformation of the way in which organizations undertake their business. In part, sustainability awareness has been spurred by the CSR movement which has gained a strong footing for in the last decade. According to Junior, Cotter, and Best (2014), sustainability practices in organizations have been used as a lens for gauging the level of a firm's environmental and social performance. Such practices have been instrumental in the birth of the modern form 
of corporate sustainability that guides decision-making on economic activities, social practices, and the financial focus in organizations. In fact, according to Albertini (2013), and Dixon-Fowler et al. (2013), corporate sustainability has expanded the financial/economic bottom-line to the TBL to include the social and environmental dynamics of corporate performance.

Finally, as observed by Jasch (2015) and Kuhlman and Farrington (2010), global governance and economic globalization has spurred an increase in the level of corporate sustainability practices in organizations as driven by the need for climate change and use of natural energy and resources. As a result, businesses have gone to the length of adopting a more integrated approach towards managing and reporting sustainability activities. In this quest, they have developed an integrated sustainability practices framework that guides business activities as regards financial disclosure and corporate governance practices, with the aim of remaining transparent to the outside world in an attempt to demonstrate sustainable development consciousness (Albertini, 2013; Haffar \& Searcy, 2017) In fact, organizations have become more adaptable to changing social and environmental dynamics, and continue to adapt through socially just and ecologically sustainable practices. Consequently, today corporate sustainability, sustainable development, and sustainability are used interchangeably and have attracted more consideration as consumers, organizations, and investors turn their focus towards increasingly expanding beyond short-term and narrow financial goals to incorporate social, economic, and environmental responsibility (Ameer \& Othman, 2012; Haffar \& Searcy, 2017; Lourenço et al., 2014).

\section{Definitions}

In an era of great awareness, sustainability has become exceedingly relevant to society and to organizations and is inevitably becoming a relevant concept in management decision-making endeavors, accounting practice, and reporting practice (Burritt \& Schaltegger, 2010; Gray, 2010; Guidry \& Patten, 2010; Windolph et al., 2014). Nonetheless, there is no universally accepted definition of sustainability (Gray \& Bebbington, 2001; Gray, 2010). The past and present literature has perpetuated brought about varied definitions of sustainability based on CSR thinking and, given the considerable theoretical streams informing views on sustainability, it has become practically impossible to extract a comprehensive definition by exhaustively reviewing the literature on the subject. To begin with, it is important to trace the definition of sustainability from the 1987 Brundtland Commission, which coined both that term and sustainable development-development focused on meeting present needs without compromising the inherent ability to meet the future needs of future generations (O'Dwyer \& Owen, 2005).

Conversely, this definition is quite encompassing and tends to leave numerous details vulnerable for to unending discourse. Although the definition has not been universally accepted, it offers a broad framework for use by scholars to 
narrow down the elements of sustainability (Windolph et al., 2014). As can be deduced from the definition, sustainability is anthropocentric because future and current generations are at its very centre (Gray \& Bebbington, 2001). Furthermore, sustainability is focused on satisfying needs, not wants. Again, sustainability is intergenerational, hence both future and current humans and their needs are of equal significance. Lastly, sustainability is deemed to be intragenerational in that the sustainability needs of developed and developing countries carry equal weight.

In addition, sustainability and CSR have been used interchangeably, and their definitions have been used by many authors (Igalens \& Gond, 2005; Van der Woerd \& Van de Brink, 2004). To ascertain the link between the definitions, it is important to articulate a definition of CSR. Corporate social responsibility entails the continued commitment by organizations to ethical conduct in their business activities while contributing to economic prosperity and improving the quality of life of their employees and their families, while remaining responsive to the needs of society and local communities (Watts \& Holme, 1999). Based on this definition, modern definitions of sustainability tend to embrace both sustainable development and CSR concepts (Hahn \& Kühnen, 2013; Windolph et al., 2014). In the business context, sustainability is defined in terms of the undertaking of activities or processes that do not produce irreversible consequences for the environment, continually remain economically feasible, and extend benefits to local community. Therefore, the interaction between social, economic, and environmental factors forms the pillars that support sustainability. By definition, economic factors are the drivers of investments, profitability, and reducing or managing costs. Social factors entail the collective needs of members of society, including equal opportunities, standards of living, access to jobs and education, and access to healthcare, among others. Environmental factors involve ecological aspects (Dyllick \& Hockerts, 2002; Wheeler \& Elkington, 2001).

Informed by these dynamics, authors have derived three definitions of sustainability: 1) ecological sustainability, 2) social sustainability, and 3) economic sustainability (O’Dwyer \& Owen, 2005; Wheeler \& Elkington, 2001). Environmental sustainability is defined as the ability to maintain the stability of the disruptive bond between the living world and human culture by means of sustainable practices such as pollution prevention and the harnessing of renewable resources. Social sustainability involves the inherent ability of the social system to operate in a socially acceptable and sustainable way while improving quality of life. Economic sustainability entails production and investment endeavors that support long-term financial stability without negatively impacting on the cultural, social, and environmental aspects of society. In this context, organizations can operationalize the objectives of sustainability by considering their social, economic, and environmental effects on society stakeholders (Dyllick \& Hockerts, 2002; Wheeler \& Elkington, 2001). 


\section{Similarities and Differences between CSR and Sustainability}

A variety of academic literature utilizes the notions of both CSR and sustainability to denote to social and environmental management matters, but there is no sharp-cut distinction between the two terms. Montiel (2008) holds that the concepts and measures of CSR and Sustainability seem to be converging, even though there are some differences between them (Montiel, 2008). Though, other scholars claim that CSR and sustainability have mutual similarities, there are indirect differences between the two terms (Millar, 2013).

Some researchers agree that although the concepts of CSR and sustainability may seem dissimilar at first, there is an inseparable link between CSR and business sustainability, or they are interchangeable (Ingram, 2013; Millar, 2013; Montiel, 2008). Any attempt to distinguish the difference between CSR and sustainability is like "splitting hairs" (Millar, 2013).

Montiel (2008) believes that current research shows there is a convergence of CSR and sustainability due to their shared environmental and social concerns, though they employ different paradigms. In practice, a socially responsible or sustainable business must address economic prosperity, social equity, and environmental integrity. Conceptually, CSR integrates economic, social, and environmental dimensions, which are very similar to the Triple Bottom Line conceptualization of sustainability comprising economic, social and environmental considerations. Both CSR and sustainability require the business firm to coordinate the basic elements of Triple Bottom Line in order to achieve long-term sustainability and social responsibility (Montiel, 2008). There are also similarities in how CSR and corporate sustainability researchers apply their constructs to measure social and environmental performance. Montiel (2008) discovered that both groups of CSR and sustainability scholars adopt similar variables to measure CSR and sustainability (Montiel, 2008). CSR variables include ethics policy, philanthropic contributions, stakeholder relationships, urban development, minority support programs, health and safety initiatives, pollution abatement programs, and conservation of natural resources. Besides environmental dimensions such as employee eco-initiatives, voluntary environmental restoration, eco-design practices, and systematically reducing waste and emissions from operations, sustainability variables also capture economic and social dimensions, such as government relationships, stakeholder interests, health and safety, and community development. "The measures and variables of the triple bottom line sustainability vision are similar with those of the three-dimensional CSR vision" (Montiel, 2008: p. 262).

Though CSR and sustainability share common similarities, there are still some subtle differences between these two terms, which have been debated for a long time (Millar, 2013). Ingram (2013) holds that CSR refers to doing business in ways that benefit, rather than harm, society and the environment, while business 
sustainability refers to a company's ability to survive into the future and to eventually outlive its current owners. Millar (2013) claims that sustainability is more inclined to make the company greener, energy-efficient, and taking care of humanity and profit, whereas traditional CSR doesn't comprise of the commitment to the environment. Millar (2013) further argues that some scholars simply say that sustainability is a component of CSR, and that the two are not mutually exclusive, while others say that CSR is one of the "Ps" in people, profit, and planet - another reference to sustainability (Millar, 2013). Montiel (2008) discovers that during the 1970s some researchers (e.g. Adizes \& Weston, 1973; Alexander \& Buchholz, 1978) only concentrated on social issues without considering environmental issues in CSR conceptualization, and others (e.g. Agle, Mitchell, \& Sonnenfeld, 1999; Graves \& Waddock, 1994; Turban \& Greening, 1997) considered that environmental issues are merely a subset of social issues. As for sustainability, some scholars just identify sustainability as simply one approach to CSR, or vice versa. They also list CSP, corporate citizenship, issues management and cause-related marketing as alternative approaches. Montiel (2008) continues to argue that though the CSR and CS constructs share similar conceptualizations of economic, social, and environmental dimensions, scholars tend to ask different questions about them. Scholars of sustainability tend to claim that the economic, social, and environmental pillars are interconnected, whereas most empirical CSR and CSP research treats social and economic performance as independent components. Further, the relationship between economic and social performance is still obscure, though a great number of quantitative analysis has been performed in this regard during the 1980s (Montiel, 2008). Montiel (2008) also holds that there are multiple definitions of CSR and the boundaries are blurry because different scholars research with different approaches. For instance, some researchers only study a single issue such as philanthropy (e.g. Brammer \& Millington, 2005), whereas others combine a range of issues into a single construct, such as governance, pollution, and diversity (e.g. Abbott \& Monsen, 1979). On the contrary, there are less issues to sustainability research, mainly because sustainability is a new area, and it benefits from having a seminal document (the WCED definition) that grounds much of the research (Bansal, 2005; Sharma \& Henriques, 2005).

Carroll (1979) argues that the business institution is the basic economic unit in our society. As such it has a responsibility to produce goods and services that society wants, and to sell them at a profit. All other business roles are predicated on this fundamental assumption (Carroll 1979). According to Bansal (2005), the economic dimension of sustainability is the economic prosperity achieved through value creation, "Firms create value through goods and services they produce. Therefore, firms increase the value created by improving the effectiveness of those goods and services efficiently" (Bansal, 2005: p. 100). In pursuance with CSR as defined by Carroll (1979), social responsibility is a supplement to economic prosperity, which is the primary fundamental responsibility of busi- 
ness, while Bansal regards social, environmental, and economic responsibilities as complementary in his definition of sustainability. Consequently, Bansal (2005) holds that the three elements must be integrated in order to achieve a sustainable outcome in a business firm. From the perspective of business implementation of CSR and sustainability initiatives, though there are much more differentiations than similarities in their comparison, Montiel (2008) claims that a combination of some elements of CSR and sustainability might lead to a much better definition for firms that are working towards becoming sustainable and socially responsible. In order to be more practical in implementation, it is recommended that business firms use both CSR and sustainability as interchangeably (Montiel, 2008). In the same fashion, other scholars (e.g., Mpofu \& Karedza 2013) also proclaim that CSR is frequently used interchangeably with sustainability, along with terms such as corporate citizenship sustainable development, Triple Bottom Line, corporate ethics, and, in some cases, corporate governance.

\section{Construct and the Conceptualization of Sustainability}

The main constructs that inform the concept of sustainability have flourished in the past few decades, adding more uncertainty to the blurred line between sustainability and CSR (Bansal, 2005; Ballou, Heitger, \& Hall, 2006; Carroll \& Shabana, 2010). According to Ballou et al. (2006) and Montiel (2008), sustainability lacks commonly accepted, well-defined, and clearly bounded constructs. Indeed, this is evidenced by the interchangeable use of CSR and sustainability or corporate sustainability (CS) without an unambiguous distinction between them. Gray (2010) notes that the concept of sustainability remains elusive and complex and tends to be overly weighed down by potential or inevitable contradictions stemming from the use of CSR constructs and the simultaneous application of economic performance dimensions. The contradictions yield tensions between financial/economic performance and the social dimension, as informed by stakeholders' needs and institutional pressures that converge with the environmental and financial needs of investors, employees, society, partners, and customers. As observed by Dyllick and Hockerts (2002) and Fifka (2012), conflicts between the social and financial dimensions may arise given the demands of society for flexibility and freedom from the financial dimensions in order to yield solutions to communal problems, while, logically, financial constraints based on firm's productivity limit the pursuing of social performance.

As noted by Chabrak (2015), in the past, research on social issues has been premised on CSR, while research on environmental issues has been grounded in environmental management. Nonetheless, in the recent past, sustainability has entered and complicated the discourse further by blurring the boundaries of studies. However, according to Montiel (2008), despite evolving from varied histories, both sustainability and CSR pursue the common goal of balancing economic/financial responsibilities with environmental/ecological and social ones. To some extent, CSR has been identified as one move towards conceptua- 
lizing sustainability or CS or vice versa. The majority of sustainability or CS scholars talk about paradigmatic issues from an eco-centric perspective, while CSR arguments focus on business issues from within the anthropocentric paradigm. As noted by Przychodzen and Przychodzen (2013), sustainability has evolved from just being merely an environmental idea focused on the conservation of resources to an indispensable milestone in business community realms. As $\mathrm{Yu}$ and Zhao (2015) observe, the widely used definition of sustainability emerged from the ideals of TBL which focus on environmental responsibility, economic feasibility, and social responsibility. As Dyllick and Hockerts (2002) and Joseph (2012) note, businesses focusing on economic viability are driven by short-term objectives, while, in order to attain future prosperity, the focus should on satisfying the three pillars. Additionally, Dyllick and Hockerts (2002) and Yu and Zhao (2015) acknowledge that when swapping CS to the corporate echelons, sustainability should focus on meeting the needs of all stakeholders without compromising an organization's ability to meet the future needs of all stakeholders.

In contributing to the discourse on the conceptualization of sustainability, Murray, Haynes and Hudson (2010) and Przychodzen and Przychodzen (2013) observe that while CSR focuses on the socio-environmental dimension of business activities, the concept of sustainability yields to comprehensive sustainable development through its tri-dimensional construct: environmental, economic dynamic, and social aspects. A clearer conceptualization of sustainability is proposed by the use of CS terminology when referring to the tri-dimensional construct, and the CSR terminology when focusing on only the social aspect of business (Montiel \& Delgado-Ceballos, 2014). Most importantly, for Hahn \& Kühnen (2013) CSR and sustainability progressively converge and end up pursuing consistent outcomes, despite the conflicting viewpoints scholars. Ideally, sustainability is more encompassing because it aims at value creation by focusing on the broader perspective of CSR or corporate governance to meet the multiple needs or interests of stakeholders by ensuring effective accountability regarding social, economic, and environmental constructs.

The most intriguing insight is that different empirical works have drawn diverse conclusions on the CS or sustainability concept. Bansal (2005) notes that sustainability encompasses environmental, economic, and social dimensions, while CSR is premised on environmental and social dimensions. Nonetheless, Hahn and Kühnen (2013) acknowledge that the existing literature is seemingly far from taking an inclusive or an encompassing view on the adoption and reporting of the three sustainability or CS dimensions. In Fifka's (2012) empirical view, the paradigm shifts in the use of CS or sustainability and CSR terminologies have only added to the existing complexity regarding the use of the tri-dimensional constructs or the focus on the environmental and social dimensional constructs. In contrast, Freundlieb, Gräuler and Teuteberg (2013) and Montiel (2008) indicate that there are no differences between CSR and CS or 
sustainability concepts as their application by organizations is meant to guide business activities towards a balance between financial commitments and socio-environmental aspects. Additionally, according to Siew (2015), the practice of CSR and CS or sustainability in organizations is both synonymous and premised on voluntary activities or endeavors, rather than on coerced mandates. Nonetheless, Dyllick and Hockerts (2002), Fifka (2012), and Montiel and Delgado-Ceballos (2014) call for restraint when using CS or sustainability and CSR interchangeably, as sustainability tends to focus primarily on simultaneously satisfying economic, environmental, and social standards, whereas CSR focuses only on satisfying just a third of the entire sustainable development undertaking.

\section{Sustainability Importance and Drivers}

The importance of sustainability can be examined based on recent trends and the related literature, and by looking at broader themes such as the environment, cultural and social significance, systems, and process improvements, as well as protection and growth (Chen \& Bouvain, 2009; Kolk, 2004). As discussed by Lu, Abeysekera, and Cortese (2015), Carnevale and Mazzuca (2014), and Saleh, Zulkifli and Muhamad (2010), sustainability practices require financial investment for implementing and timeously reporting on socially responsible practices and consequently promote the positive culture of safeguarding the environment through a harmonious relationship between humans and nature. In fact, sustainability is at the core of creating and acknowledging awareness of the broader environmental issues that indirectly or directly affect organizations. Adopting sustainability or CS practices is critical to guide the organization towards attaining the desired environmental quality in order to attain healthy communities which are epitomized by a non-toxic environment, clean air, and the responsible use of natural resources (Carnevale \& Mazzuca, 2014; Lu et al., 2015; Saleh et al., 2010).

Furthermore, according to Chen and Bouvain (2009) and Lu et al. (2015), sustainability practices in organizations help in supporting community needs, acknowledging the cultural ideas of society, and creating useful partnerships that demonstrate social responsibility. Sustainability acts as the pedestal that propels organizations towards socio-cultural responsibility and prioritizing the fulfillment of pressing present and future community needs. In support of this view, Kolk (2004), Montiel and Delgado-Ceballos (2014), and Michelon and Parbonetti (2012) conclude that sustainability is the benchmark for guiding corporations towards greater transparency on social issues and for effective tracking of the progress that has been made by in improving communities. Through sustainability, organizations are able to continually improve systems and processes by adapting to changing external dynamics, including climate change and community needs (Lu et al., 2015; Saleh et al., 2010). Improving systems and processes is critical to ensuring a sustainable manner of producing, making profits, and utilizing the available workforce and natural resources. 
Most importantly, following this review of the importance of sustainability, recent interest in CS or sustainability has directed studies towards ascertaining the major drivers of sustainability practices in organizations. As evidenced by Akbas (2016), Bani-Khalid, Kouhy, and Hassan (2017), and Bayoud, Kavanagh, and Slaughter (2012), and Gray \& Bebbington (2001), and Nguyen et al. (2017), company characteristics have been the main driver of sustainability practices in organizations. In examining factors that drive sustainability practices, Nguyen et al. (2017) conclude that company attributes such as age and size tend to influence sustainability culture and related disclosure practices. Gray \& Bebbington (2001) and Trencansky and Tsaparlidis (2014) support this view by indicating that the age, type, and size of a company tend to influence sustainability practices. In this context, larger and experienced firms, as well as organizations dealing with production activities that negatively affect the environment, tend to embrace CS or sustainability practices. However, Bayoud et al. (2012) and Gray \& Bebbington (2001) assert that highly profitable, larger firms with a longer history in an industry tend to focus on sustainability practices to a greater extent than do unprofitable ones. Nonetheless, Akbas (2016) feel that a company's age is negatively correlated with sustainability practices. Bani-Khalid, Kouhy and Hassan (2017) make a similar observation, indicating that the type of industry and the age of the company do not influence sustainability practices; rather, the size of the organization affects sustainable development and disclosure practices.

According to Albawwat et al. (2015), Alhazaimeh, Palaniappan and Almsafir (2014), Bani-Khalid et al. (2017), and Dibia and Onwuchekwa (2015), another driver of sustainability is a company's governance attributes. Studying governance attributes, Alhazaimeh et al. (2014) establish a positive correlation between voluntary sustainability practices and board size. Conversely, Khan (2010) and Rouf (2011) conclude that there is a positive correlation between voluntary sustainability practices and the existence of an audit committee. This perspective is supported by Bani-Khalid et al. (2017) and Samaha, Khlif and Hussainey's (2015) findings which indicate that audit committee and boards of directors' attributes significantly affect sustainability practices by influencing internal processes and practices and CSR practices. A similar view is supported by the fact that regular board meetings and board size influence the decisions made regarding sustainability and sustainable development practices (Alhazaimeh et al., 2014). Nonetheless, studies by Albawwat et al. (2015) and Elfeky (2017) demonstrate a negative correlation between voluntary sustainability and board size, the frequency of board meetings, and the existence of an audit committee. In fact, there is no positive influence of the type of audit firm on voluntary sustainability practices. Other studies have established that the number or proportion of board members present of some independent audit committee members and the mere existence of an audit committee positively influence the rate of sustainability practices by an organization (Alhazaimeh et al., 2014; Michelon \& Parbonetti, 2012). 
In addition, Khan (2010), and Said et al. (2017) indicate that a company's ownership structure is a significant driver of sustainability practices. Said et al.'s (2017) empirical findings on ownership structure and the sustainability activities of an organization show that a government stake in an organization and a board compensation structure tend to significantly influence sustainability activities in organizations. In fact, Haddad et al. (2015) and Michelon and Parbonetti (2012) have established that the level of sustainability practices is greatly influenced by a larger government ownership base. Nonetheless, findings by Albawwat et al. (2015) indicate negative correlations between voluntary CS practices and block foreign ownership, the number of shareholders, and block-holder ownership structure. A similar observation is made by Edmans (2014), whose findings indicate that ownership structure and concentrated efforts as regards sustainability practices do not positively influence CS or CSR activities. However, Khan (2010) concludes that the presence of a powerful personality who influences decisions and the control of an organization tends to significantly influence sustainability practices and CSR commitments. Supporting this view, Ghazali (2007) and Prado \& Sánchez (2010) established a positive correlation between sustainability practices and the controlling role of the largest stockholder of a company. It can be concluded that the possibility that ownership structure either negatively and positively influences sustainability practices is conceivable; future research is bound to shed more empirical light on this.

\section{Models of Sustainability}

The existing literature has documented various models of sustainability that embody the chronological conceptualization of the concept, signifying a paradigm shift from environmental constructs to social, economic, and environmental constructs (Todorov \& Marinova, 2009). Boulanger and Bréchet (2005) articulate five crucial methodological criteria for developing models of sustainability, namely: 1) an interdisciplinary approach, 2) a local/global perspective, 3) an intergenerational perspective, 4) stakeholders' participation, and 5) managing uncertainty. In this context, a number of model classifications exist, including models that are visualized pictorially, physical models, quantitative models, standardizing models, and conceptual models (Newman \& Kenworthy, 1999; Todorov \& Marinova, 2009). The pictorial visualization models use Venn diagrammatic representations to stress the value of the interactive dimensions of sustainability. Despite their weaker explanatory power, such models underline the importance of trans-disciplinary and interdisciplinary approaches to comprehending the concept of sustainability (Todorov \& Marinova, 2009). A good illustration is Newman and Kenworthy's (1999) model which emphasizes the interaction between key sustainability constructs, including social development/responsibility, economic development/responsibility, and environmental improvement and protection. In Figure 1, this model indicates the manner in 


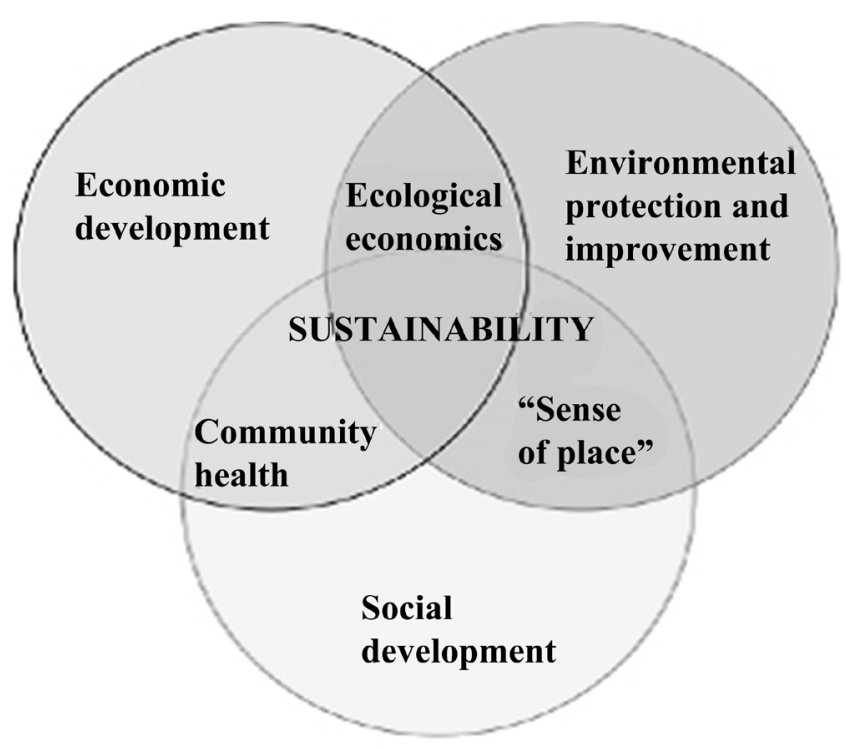

Figure 1. Newman and Kenworthy's (1999) sustainability model.

which sustainability is attained by way of social responsibility, in terms of social development that yields community health or well-being for future and current generations. The model demonstrates the need for economic responsibility by way of consideration of ecological economies, as well as the value of continually improving and protecting the environment by means of social considerations, and as enabled by considerations of ecological economics.

The physical models tend to restrict their focus to the environmental component and have mainly been used in implementing industry ecology and handling the menace of pollution. These models are quite local and very specific and emphasize interdisciplinary perspectives, as well as a participatory approach to attaining sustainability by way of human-generated physical features such as buildings and natural resource harnessing systems (Hellström, 2000). An applicable example is Hannon, Ruth and Delucia's (1993) model that acknowledges the negative effects of human activities on the natural environment through intrusive means, which result in decreasing environmental quality. The model emphasizes the need for using human interventions to ensure a balanced ecosystem when using or depleting energy and related resources. To attain sustainability, the model calls for group participation from ecological stakeholders, economic entities, and the social context.

The conceptual models are intergenerational, have a long-term orientation, and focus on the paradigm changes that inform sustainable development, including evolutionary concept, climate change and global warming, and the depletion of natural resources (Costanza et al., 1993). A good illustration of a conceptual model is that of Carter and Rogers (2008). Using a Venn diagram, the model demonstrates the value for interlinking social performance, economic performance, and environmental performance in attaining sustainability (see Figure 2). Organizations are encouraged to develop a culture of sustainable development that 


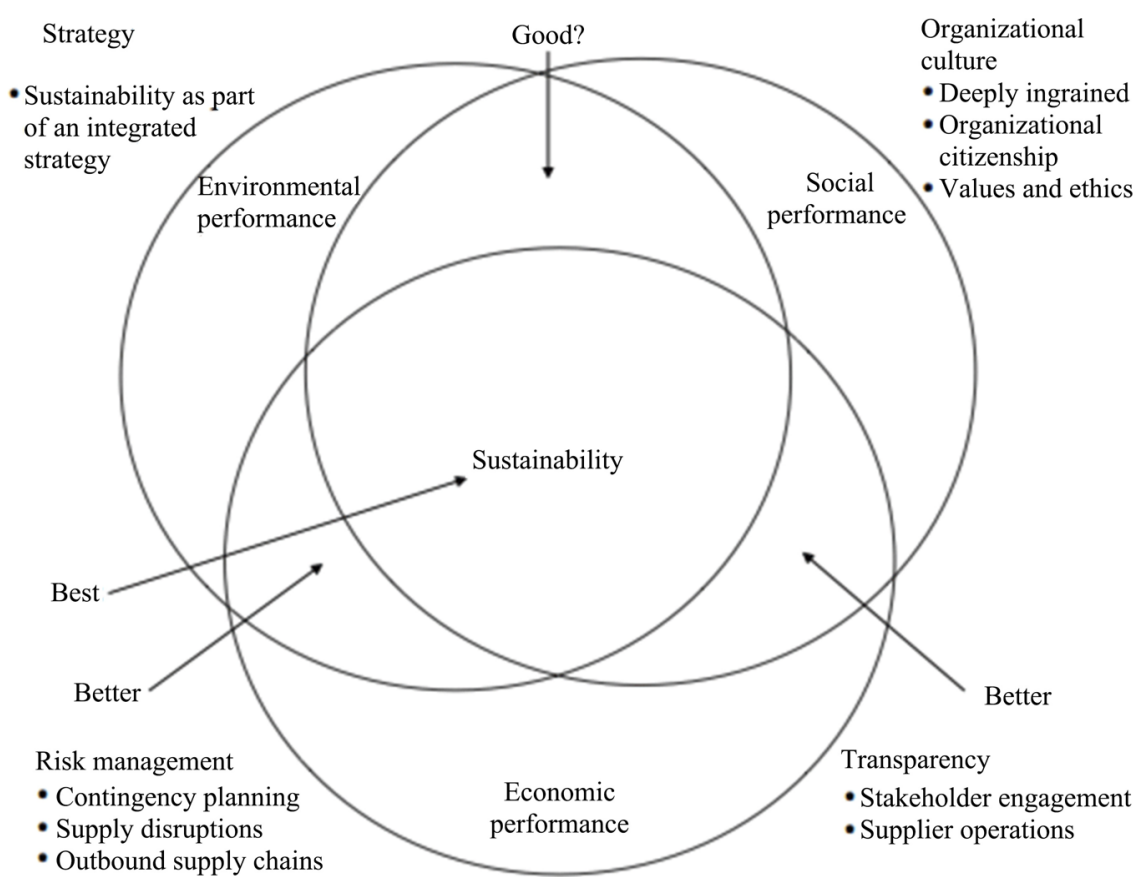

Figure 2. Carter \& Rogers' (2008) sustainability model.

informs an integrated strategic approach to managing social performance, economic performance, and environmental performance by way of risk management practices and transparency or disclosure to stakeholders.

The standardizing models focus on applying and developing sustainability indicators to ascertain performance in each dimension, as well as explaining the complex interaction between the ecological health, social, and economic dimensions (Bell \& Morse, 2000). Such models measure the level of sustainability of an organization or an entity by relating the factors to the major dimensions using empirical, empirical, axiological, and mathematical standardization. The largest challenges or weaknesses of these models have been the justifications for the specific weights used in standardizing the sustainability dimensions. A good illustration is Boulanger's (2008) which emphasizes the use of sustainable development indicators to guide organizations to efficiency and levels of resilience (see Figure 3). The model demonstrates the construction of sustainability indicators and their practical standardization using empirical, mathematic, statistical, and axiological standardization. It demonstrates that the social, economic, and environmental dimensions are the pillars that yield sustainable development if they are effectively managed and measured using scientific indicators.

Finally, the quantitative models are academic pursuits of sustainability informed by system dynamics, the optimization of resource use, and equilibrium among the dynamics or dimensions acting on sustainable development (Bell \& Morse, 2000; Diesendorf, 2000). Such models have no specific orientation but are rather informed by the specific discipline they seek to represent, such as economics, accounting, and environmental science, among others. An excellent 


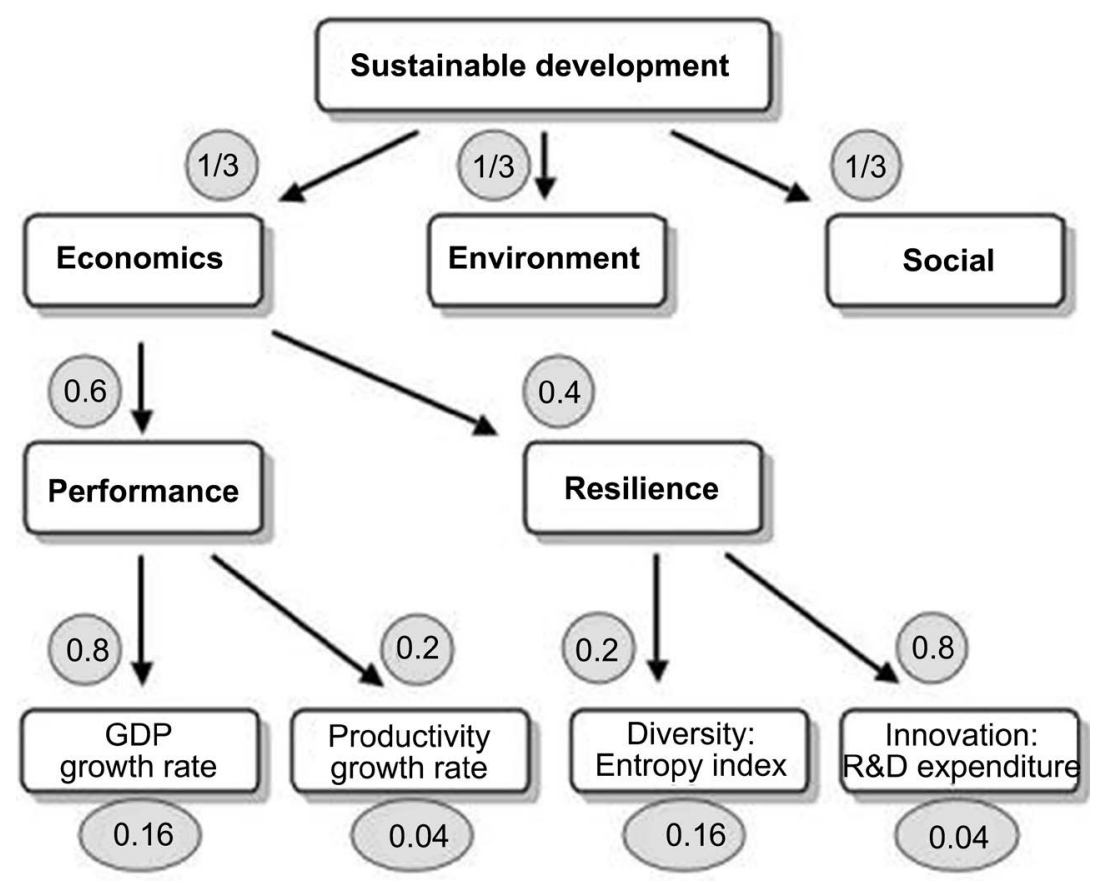

Figure 3. Boulanger's (2008) sustainability model.

example is Diesendorf's (2000) which proposes four logical sustainability levels, namely: 1) Level 0-ethical principles/responsibility, 2) Level 1-the broad goals for enhancing intra- and intergenerational equity, ecological integrity, human well-being, and biodiversity, 3) Level 2-sustainability indicators based on the environmental, economic, and social dimensions, and (d) Level 3-the action plan for implementing the sustainability ideals based on the preceding levels. The model uses this four-tier approach for managing sustainability practices in organizations by calling for an integrated approach to the social, economic, and environmental dimensions without of any tradeoffs. The model encourages organizations' leadership to engage in community empowerment and participation in order to create a vision of sustainable development to inform a sustainability policy.

\section{Conclusion}

This paper has clarified the historical background and emergence of sustainability, as well as the constructs and conceptualizations of sustainability from the 1960s to the present day. A detailed analysis of the conceptualization and definition of sustainability indicates that there is no universally acceptable definition of the term "sustainability". Therefore, there appears to be a conceptual gap which the current study addresses by contributing theoretical views on the concept of sustainability and related constructs. However, based on the literature reviewed, there is agreement on the basic elements of sustainability-it should encompass environmental, social, and economic constructs. Furthermore, the thin line between CS or sustainability and CSR has been noted, with the latter see- 
mingly contributing a small part of the holistic concept of sustainable development. With the synthesized knowledge generated from the literature review, it is evident that sustainability or CS practice is primarily driven by ownership structure, company characteristics, and governance attributes. Finally, the paper has presented relevant and diverse models of sustainability that inform the current research, including pictorial visualization models, physical models, quantitative models, standardizing models, and conceptual models.

\section{Conflicts of Interest}

The author declares no conflicts of interest regarding the publication of this paper.

\section{References}

Abbott, W. F., \& Monsen, R. (1979). On the Measurement of Corporate Social Responsibility: Self-Reported Disclosure as Method of Measuring of Corporate Social Involvement, Academy of Management Review, 22, 501-515. https://doi.org/10.5465/255740

Adizes, I., \& Weston, J. F. (1973). Comparative Models of Social Responsibility. Academy of Management Journal, 16, 112-128. https://doi.org/10.2307/255047

Agle, B. R., Mitchell, R. K., \& Sonnenfeld, J. A. (1999). Who Matters to CEOs? An Investigation of Stakeholder Attributes and Salience, Corporate Performance and CEO Values. Academy of Management Journal, 42, 507-525. https://doi.org/10.5465/256973

Akbas, H. (2016). The Relationship between Board Characteristics and Environmental Disclosure: Evidence from Turkish Listed Companies. South East European Journal of Economics and Business, 11, 7-19. https://doi.org/10.1515/jeb-2016-0007

Albawwat, A., Ali Basah, M. Y., \& Khairi, K. (2015). An Exploratory Study on Voluntary Disclosure and Interim Financial Reporting in Jordan. International Journal of Accounting Research, 3, Article ID: 1000119. https://doi.org/10.5296/jpag.v5i2.7580

Albertini, E. (2013). Does Environmental Management Improve Financial Performance? A Meta-Analytical Review. Organization \& Environment, 26, 431-457. https://doi.org/10.1177/1086026613510301

Alexander, G., \& Buchholz, R. (1978). Corporate Social Responsibility and Stock Market Performance. The Academy of Management Journal, 21, 479-486.

https://doi.org/10.5465/255728

Alhazaimeh, A., Palaniappan, R., \& Almsafir, M. (2014). The Impact of Corporate Governance and Ownership Structure on Voluntary Disclosure in Annual Reports among Listed Jordanian Companies. Procedia-Social and Behavioral Sciences, 129, 341-348. https://doi.org/10.1016/j.sbspro.2014.03.686

Ameer, R., \& Othman, R. (2012). Sustainability Practices and Corporate Financial Performance: A Study Based on the Top Global Corporations. Journal of Business Ethics, 108, 61-79. https://doi.org/10.1007/s10551-011-1063-y

Ballou, B., Heitger, D. L., Landes, C. E., \& Adams, M. (2006). The Future of Corporate Sustainability Reporting. Journal of Accountancy, 202, 65-74.

Bani-Khalid, T., Kouhy, R., \& Hassan, A. (2017). The Impact of Corporate Characteristics on Social and Environmental Disclosure (CSED): The Case of Jordan. Journal of Accounting and Auditing: Research \& Practice, 2017, Article ID: 369352.

https://doi.org/10.5171/2017.369352 
Bansal, T. (2005). Evolving Sustainably: A Longitudinal Study of Corporate Sustainable Development. Strategic Management Journal, 26, 197-218.

https://doi.org/10.1002/smj.441

Bayoud, N. S., Kavanagh, M., \& Slaughter, G. (2012). Factors Influencing Levels of Corporate Social Responsibility Disclosure by Libyan Firms: A Mixed Study. International Journal of Economics and Finance, 4, 13-29. https://doi.org/10.5539/ijef.v4n4p13

Bell, S., \& Morse, S. (2000). Sustainability Indicators: Measuring the Immeasurable. Journal of Rural Studies, 16, 395. https://doi.org/10.1016/S0743-0167(99)00036-4

Boulanger, P.-M. (2008). Sustainable Development Indicators: A Scientific Challenge, a Democratic Issue. Sapiens Journal, 1, 45-59. https://doi.org/10.5194/sapiens-1-59-2008

Boulanger, P.-M., \& Bréchet, T. (2005). Models for Policy-Making in Sustainable Development: The State of the Art and Perspectives for Research. Ecological Economics, 55, 337-350. https://doi.org/10.1016/j.ecolecon.2005.07.033

Brammer, S., \& Millington, A. (2005). Corporate Reputation and Philanthropy: An Empirical Analysis. Journal of Business Ethics, 61, 29-44.

https://doi.org/10.1007/s10551-005-7443-4

Brown, H., Jong, W. M., \& Levy, D. (2009). Building Institutions Based on Information Disclosure: Lessons from GRI's Sustainability Reporting. Journal of Cleaner Production, 17, 571-580. https://doi.org/10.1016/j.jclepro.2008.12.009

Burritt, R. L., \& Schaltegger, S. (2010). Sustainability Accounting and Reporting: Fad or Trend? Accounting, Auditing \& Accountability Journal, 23, 829-846.

https://doi.org/10.1108/09513571011080144

Carnevale, C., \& Mazzuca, M. (2014). Sustainability Report and Bank Valuation: Evidence from European Stock Markets. Business Ethics: A European Review, 23, 69-90. https://doi.org/10.1111/beer.12038

Carroll, A. B. (1979). A Three-Dimensional Conceptual Model of Corporate Performance. The Academy of Management Review, 4, 497-505.

Carroll, A. B. (1999). Corporate Social Responsibility: Evolution of a Definitional Construct. Business and Society, 38, 268-295. https://doi.org/10.1177/000765039903800303

Carroll, A., \& Shabana, K. (2010). The Business Case for Corporate Social Responsibility: A Review of Concepts, Research and Practice. International Journal of Management Reviews, 12, 85-105. https://doi.org/10.1111/j.1468-2370.2009.00275.x

Carter, C. R., \& Rogers, D. S. (2008). A Framework of Sustainable Supply Chain Management: Moving toward New Theory. International Journal of Physical Distribution \& Logistics Management, 38, 360-387. https://doi.org/10.1108/09600030810882816

Chabrak, N. (2015). Promoting Corporate Social Responsibility and Sustainability: A Model of Integrity. Society and Business Review, 10, 280-305.

https://doi.org/10.1108/SBR-06-2015-0018

Chen, S., \& Bouvain, P. (2009). Is Corporate Responsibility Converging? A Comparison of Corporate Responsibility Reporting in the USA, UK, Australia, and Germany. Journal of Business Ethics, 87, 299-317. https://doi.org/10.1007/s10551-008-9794-0

Costanza, R., Wainger, L., Folke, C., \& Mäler, K.-G. (1993). Modeling Complex Ecological Economic Systems. Bioscience, 43, 545-555. https://doi.org/10.2307/1311949

Deegan, C. M. (2002). The Legitimising Effect of Social and Environmental Disclosures-A Theoretical Foundation. Accounting, Auditing \& Accountability Journal, 15, 282-311. https://doi.org/10.1108/09513570210435852

Dibia, N. O., Onwuchekwa, J. C. (2015). Determinants of Environmental Disclosures in 
Nigeria: A Case Study of Oil and Gas Companies. International Journal of Finance and Accounting, 4, 145-152.

Diesendorf, M. (2000). Sustainability and Sustainable Development. In D. Dunphy, J. Benveniste, A. Griffiths, \& P. Sutton (Eds.), Sustainability: The Corporate Challenge of the 21st Century (pp. 19-37). Allen \& Unwin.

Dixon-Fowler, H. R., Slater, D. J., Johnson, J. L., Ellstrand, A. E., \& Romi, A. M. (2013). Beyond "Does It Pay to Be Green?" A Meta-Analysis of Moderators of the CEP-CFP Relationship. Journal of Business Ethics, 112, 353-366. https://doi.org/10.1007/s10551-012-1268-8

Dragomir, V. (2011). Accounting for Sustainability: The Quest for a Conceptual Framework. International Journal of Critical Accounting, 3, 384-398. https://doi.org/10.1504/IJCA.2011.042930

Dyllick, T., \& Hockerts, K. (2002). Beyond the Business Case for Corporate Sustainability (p. 11). University of St. Gallen. https://doi.org/10.1002/bse.323

Edmans, A. (2014). Blockholders and Corporate Governance. Annual Review of Financial Economics, 6, 23-50. https://doi.org/10.1146/annurev-financial-110613-034455

Elfeky, M. (2017). The Extent of Voluntary Disclosure and Its Determinants in Emerging Markets: Evidence from Egypt. The Journal of Finance and Data Science, 3, 45-59. https://doi.org/10.1016/j.jfds.2017.09.005

Elkington, J. (1999). Cannibals with Forks: The Triple Bottom Line of 21st Century Business. Capstone. https://doi.org/10.1002/tqem.3310080106

Fifka, M. (2012). The Development and State of Research on Social and Environmental Reporting in Global Comparison. Journal für Betriebswirtschaft, 62, 45-84. https://doi.org/10.1007/s11301-012-0083-8

Freundlieb, M., Gräuler, M., \& Teuteberg, F. (2013). A Conceptual Framework for the Quality Evaluation of Sustainability Reports. Management Research Review, 37, 19-44. https://doi.org/10.1108/MRR-04-2012-0087

Ghazali, N. (2007). Ownership Structure and Corporate Social Responsibility Disclosure: Some Malaysian Evidence. Corporate Governance, 7, 251-266. https://doi.org/10.1108/14720700710756535

Graves, S., \& Waddock, S. (1994). Institutional Owners and Corporate Social Performance. Academy of Management Journal, 37, 1034-1046.

https://doi.org/10.5465/256611

Gray, R. (2006). Social, Environmental and Sustainability Reporting and Organisational Value Creation? Whose Value? Whose Creation? Accounting, Auditing \& Accountability Journal, 19, 793-819. https://doi.org/10.1108/09513570610709872

Gray, R. H. (2010). Is Accounting for Sustainability Actually Accounting for Sustainability and How Would We Know? An Exploration of Narratives of Organisations and the Planet. Accounting, Organizations and Society, 35, 47-62. https://doi.org/10.1016/j.aos.2009.04.006

Gray, R. H., \& Kouhy, R. (1993). Accounting for the Environment and Sustainability in Lesser Developed Countries. Research in Third World Accounting, 2, 387-399.

Gray, R., \& Bebbington, J. (2001). Accounting for the Environment (2nd ed.). SAGE Publications Ltd.

Guidry, R., \& Patten, D. (2010). Market Reactions to the First-Time Issuance of Corporate Sustainability Reports: Evidence That Quality Matters. Sustainability Accounting, Management and Policy Journal, 1, 33-50. https://doi.org/10.1108/20408021011059214 
Haddad, N., Brudvig, L., Clobert, J., Davies, K., Gonzalez, A., Holt, R., Lovejoy, T., Sexton, J., Austin, M., Collins, C., Cook, W., Damschen, E., Ewers, R., Foster, B., Jenkins, C., King, A., Laurance, W., Levey, D., Margules, C., \& Townshend, J. (2015). Habitat Fragmentation and Its Lasting Impact on Earth Ecosystems. Science Advances, 1, e1500052. https://doi.org/10.1126/sciadv.1500052

Haffar, M., \& Searcy, C. (2017). Classification of Trade-Offs Encountered in the Practice of Corporate Sustainability. Journal of Business Ethics, 140, 495-522. https://doi.org/10.1007/s10551-015-2678-1

Hahn, R., \& Kühnen, M. (2013). Determinants of Sustainability Reporting: A Review of Results, Trends, Theory, and Opportunities in an Expanding Field of Research. Journal of Cleaner Production, 59, 5-21. https://doi.org/10.1016/j.jclepro.2013.07.005

Hannon, B., Ruth, M., \& Delucia, E. (1993). A Physical View of Sustainability. Ecological Economics, 8, 253-268. https://doi.org/10.1016/0921-8009(93)90061-A

Hellström, T. (2000). Technoscientific Expertise and the Significance of Policy Cultures. Technology in Society, 22, 499-512. https://doi.org/10.1016/S0160-791X(00)00023-3

Hyršlová, J., Becková, H., \& Kubáňková, M. (2015). Sustainability Accounting: Brief History and Perspective. The 9th International Days of Statistics and Economics, Prague, 10-12 September 2015.

Igalens, J., \& Gond, J.-P. (2005). Measuring Corporate Social Performance in France: A Critical and Empirical Analysis of ARESE Data. Journal of Business Ethics, 56, 131-148. https://doi.org/10.1007/s10551-004-3529-7

Ingram, R. (2013). Emotions, Social Work Practice and Supervision: An Uneasy Alliance? Journal of Social Work Practice, 27, 5-19. https://doi.org/10.1080/02650533.2012.745842

Jasch, C. (2015). Governmental Initiatives: The UNIDO (United Nations Industrial Development Organization) TEST Approach. Journal of Cleaner Production, 108, 1375-1377. https://doi.org/10.1016/j.jclepro.2015.10.019

Joseph, G. (2012). Ambiguous but Tethered: An Accounting Basis for Sustainability Reporting. Critical Perspectives on Accounting, 23, 93-106.

https://doi.org/10.1016/j.cpa.2011.11.011

Junior, R. M., Cotter, J., \& Best, P. J. (2014). Sustainability Reporting and Assurance: A Historical Analysis on a World-Wide Phenomenon. Journal of Business Ethics, 120, 1-11. https://doi.org/10.1007/s10551-013-1637-y

Khan, M. H. U. Z. (2010). The Effect of Corporate Governance Elements on Corporate Social Responsibility (CSR) Reporting: Empirical Evidence from Private Commercial Banks of Bangladesh. International Journal of Law and Management, 52, 82-109. https://doi.org/10.1108/17542431011029406

Kolk, A. (2004). A Decade of Sustainability Reporting: Developments and Significance. International Journal of Environment and Sustainable Development, 3, 51-64. https://doi.org/10.1504/IJESD.2004.004688

Kolk, A., \& van Tulder, R. J. M. (2010). International Business, Corporate Social Responsibility and Sustainable Development. International Business Review, 19, 119-125. https://doi.org/10.1016/j.ibusrev.2009.12.003

Kuhlman, T., \& Farrington, J. (2010). What Is Sustainability? Sustainability, 2, 3436-3448. https://doi.org/10.3390/su2113436

Lourenço, C. I., Callen, J. L., Branco, M. C., \& Curto, J. D. (2014). The Value Relevance of Reputation for Sustainability Leadership. Journal of Business Ethics, 119, 17-28. 
https://doi.org/10.1007/s10551-012-1617-7

Lu, Y. J., Abeysekera, I., \& Cortese, C. (2015). Corporate Social Responsibility Reporting Quality, Board Characteristics and Corporate Social Reputation: Evidence from China. Pacific Accounting Review, 27, 95-118. https://doi.org/10.1108/PAR-10-2012-0053

Michelon, G., \&Parbonetti, A. (2012). The Effect of Corporate Governance on Sustainability Disclosure. Journal of Management and Governance, 16, 1-33.

Millar, R. (2013). Improving Science Education: Why Assessment Matters. In Valuing Assessment in Science Education: Pedagogy, Curriculum, Policy (pp. 55-68). Springer. https://doi.org/10.1007/978-94-007-6668-6 4

Montiel, I. (2008). Corporate Social Responsibility and Corporate Sustainability: Separate Pasts, Common Futures. Organization \& Environment, 21, 245-269. https://doi.org/10.1177/1086026608321329

Montiel, I., \& Delgado-Ceballos, J. (2014). Defining and Measuring Corporate Sustainability: Are We There Yet? Organization \& Environment, 27, 113-139. https://doi.org/10.1177/1086026614526413

Mpofu, T., \& Karedza, G. (2013). Views on Corporate Social Responsibility. European Journal of Business and Management, 5, 36-39.

Munoz, E., Zhao, L. J., \& Yang, D. (2017). Issues in Sustainability Accounting Reporting. Accounting and Finance Research, 6, 64. https://doi.org/10.5430/afr.v6n3p64

Murray, A., Haynes, K., \& Hudson, L. (2010). Collaborating to Achieve Corporate Social Responsibility and Sustainability? Possibilities and Problems. Sustainability Accounting, Management and Policy Journal, 1, 161-177. https://doi.org/10.1108/20408021011089220

Newman, P., \& Kenworthy, J. (1999). Sustainability and Cities: Overcoming Automobile Dependence. Island Press.

Nguyen, T. N., Nguyen, H. V., Lobo, A., \& Dao, T. S. (2017). Encouraging Vietnamese Household Recycling Behavior: Insights and Implications. Sustainability, 9, Article No. 179. https://doi.org/10.3390/su9020179

O’Dwyer, B., \& Owen, D. (2005). Assurance Statement Practice in Environmental, Social and Sustainability Reporting: A Critical Evaluation. The British Accounting Review, 37, 205-229.

Prado-Lorenzo, J.-M., \& Sánchez, I. (2010). The Role of the Board of Directors in Disseminating Relevant Information on Greenhouse Gases. Journal of Business Ethics, 97, 391-424. https://doi.org/10.1007/s10551-010-0515-0

Prakash, S. S. (1979). A Conceptual Framework for Environmental Analysis of Social Issues and Evaluation of Business Response Patterns. Academy of Management Review, 4, 63-74. https://doi.org/10.5465/amr.1979.4289184

Przychodzen, J., \& Przychodzen, W. (2013). Corporate Sustainability and Shareholder Wealth. Journal of Environmental Planning and Management, 56, 474-493. https://doi.org/10.1080/09640568.2012.685927

Rappaport (1998). Creating Shareholder Value (Revised and Updated ed.). The Free Press.

Rouf, M. (2011). The Corporate Social Responsibility Disclosure: A Study of Listed Companies in Bangladesh. Business and Economics Research Journal, 2, 19-32.

Said, R., Sidek, N. Z., Azhar, Z., \& Kamarudin, K. A. (2017). State-of-the-Art Theories and Empirical Evidence. Selected Papers from the 6th International Conference on Governance, Fraud, Ethics, and Social Responsibility. Springer. 
https://doi.org/10.1007/978-981-10-6926-0

Saleh, M., Zulkifli, N., \& Muhamad, R. (2010). Corporate Social Responsibility Disclosure and Its Relation on Institutional Ownership: Evidence from Public Listed Companies in Malaysia. Managerial Auditing Journal, 25, 591-613. https://doi.org/10.1108/02686901011054881

Salzmann, O., Ionescu-Somers, A., \& Steger, U. (2005). The Business Case for Corporate Sustainability: Literature Review and Research Options. European Management Journal, 23, 27-36. https://doi.org/10.1016/j.emj.2004.12.007

Samaha, K., Khlif, H., \& Hussainey, K. (2015). The Impact of Board and Audit Committee Characteristics on Voluntary Disclosure: A Meta-Analysis. Journal of International Accounting, Auditing and Taxation, 24, 13-28.

https://doi.org/10.1016/j.intaccaudtax.2014.11.001

Sethi, S. P. (1975). Dimensions of Corporate Social Performance: An Analytical Framework. California Management Review, 17, 58-64. https://doi.org/10.2307/41162149

Seuring, S., \& Müller, M. (2008). From a Literature Review to a Conceptual Framework for Sustainable Supply Chain Management. Journal of Cleaner Production, 16, 1699-1710.

Sharma, S., \& Henriques, I. (2005). Stakeholder Influences on Sustainability Practices in the Canadian Forest Products Industry. Strategic Management Journal, 26, 159-180. https://doi.org/10.1002/smj.439

Siew, R. (2015). A Review of Corporate Sustainability Reporting Tools (SRTs). Journal of Environmental Management, 164, 180-195.

https://doi.org/10.1016/j.jenvman.2015.09.010

Sveiby, K.-E., Annell, E., Axelsson, S., Emilsson, P. M., Karlsson H., Wangerud, C. J., \& Vikström, S. (1990). The Invisible Balance Sheet.

Todorov, V., \& Marinova, D. (2009). Models of Sustainability.

Trencansky, D., \& Tsaparlidis, D. (2014). The Effects of Company's Age, Size and Type of Industry on the Level of CSR. The Development of a New Scale for Measurement of the Level of CSR. Master's Thesis, Umeå School of Business and Economics.

Turban, D., \& Greening, D. (1997). Corporate Social Performance and Organizational Attractiveness to Prospective Employees. Academy of Management Journal, 40, 658-672. https://doi.org/10.2307/257057

Van der Woerd, \& van den Brink, T. (2004). Feasibility of a Responsive Business Scorecard-A Pilot Study. Journal of Business Ethics, 55, 173-186. https://doi.org/10.1007/s10551-004-1900-3

Watts, P., \& Holme, R. (1999). Corporate Social Responsibility: Meeting Changing EXpectations. World Business Council for Sustainable Development.

Wheeler, D., \& Elkington, J. (2001). The End of the Corporate Environmental Report? Or the Advent of Cybernetic Sustainability Reporting and Communication. Business Strategy and the Environment, 10, 1-14.

https://doi.org/10.1002/1099-0836(200101/02)10:1<1::AID-BSE274>3.0.CO;2-0

Williams, C., \& Conley, J. (2005). An Emerging Third Way? The Erosion of the Anglo-American Shareholder Value Construct. Cornell International Law Journal, 38, 493-551. https://doi.org/10.2139/ssrn.632347

Windolph, S., Harms, D., \& Schaltegger, S. (2014). Motivations for Corporate Sustainability Management: Contrasting Survey Results and Implementation. Corporate Social Responsibility and Environmental Management, 21, 272-285.

https://doi.org/10.1002/csr.1337 
Yu, M., \& Zhao, R. (2015). Sustainability and Firm Valuation: An International Investigation. International Journal of Accounting \& Information Management, 23, 289-307. https://doi.org/10.1108/IJAIM-07-2014-0050 